\title{
Wildlife Harvest and Consumption in Amazonia's Urbanized Wilderness
}

\author{
Luke Parry $^{1,2}$, Jos Barlow ${ }^{1,2}, \&$ Heloisa Pereira ${ }^{3}$ \\ ${ }^{1}$ Lancaster Environment Centre, Lancaster University, Lancaster, LA1 4YQ, UK \\ ${ }^{2}$ Museu Paraense Emílio Goeldi (MPEG), Avenida Perimetral 1901, Bairro Terra Firme, 66077-530 Belém, Pará, Brazil \\ ${ }^{3}$ Instituto de Filosofia e Ciências Humanas, Universidade Estadual de Campinas (UNICAMP), CEP 13083-896 Campinas, São Paulo, Brazil
}

\author{
Keywords \\ Brazil; bushmeat; cities; fishing; hunting; \\ sustainability; urbanization. \\ Correspondence \\ Luke Parry, Lancaster Environment Centre, \\ Lancaster University, Lancaster, LA1 4YQ, UK. \\ Tel: +44 (0)1524 510289; \\ E-mail: luke.parry@lancaster.ac.uk \\ Received \\ 29 April 2014 \\ Accepted \\ 4 September 2014 \\ Editor \\ Edward Game
}

doi: $10.1111 /$ conl.12151

\begin{abstract}
Urbanization of forested wilderness could threaten biodiversity if expanding cities drive demand for wildlife as food. We examined the scale and drivers of urban wildlife consumption in the forested prefrontier of Brazilian Amazonia, defined as municipalities $(n=73)$ with over $90 \%$ of their original forest cover still intact. A representative survey of two prefrontier cities indicated that virtually all urban households consume wildlife, including fish (99\%), bushmeat (mammals and birds; 79\%), chelonians (48\%) and caimans (28\%)—alarming evidence of an underreported wild-meat crisis in the heart of Amazonia. We also report rapid growth of cities and inadequate resources to deter illegal consumption in this urbanized wilderness covering 1.86 million $\mathrm{km}^{2}$. We evaluate relevant policy levers and conclude that poverty-alleviation programs may accelerate a long-term transition from consumption of wildlife as an economical source of protein for the poor to luxury food for the wealthy. We argue that innovative environmental governance could limit wildlife consumption to only harvest-tolerant species. Researchers and policy-makers should engage with policies and ideas that promote poverty alleviation and supply poor citydwellers with affordable alternatives to eating wildlife.
\end{abstract}

\section{Introduction}

Irreplaceable tropical forest wilderness is essential for conserving biodiversity (Brooks et al. 2006) and is cheaper to conserve than other priority biomes because of sparse rural settlement (Joppa et al. 2008). The conservation toolkit for protecting vast areas of forest in Amazonia, Congo, and New Guinea has expanded from protected areas to include satellite monitoring of forest clearance and providing forest-dwellers with economic incentives to avoid deforestation.

There has been rapid growth of cities in the forested wilderness of Amazonia and Congo (Figure S1). These growing cities within forested wilderness regions may pose a significant yet poorly understood threat to biodiversity below the canopy (Agrawal 8 Redford 2006) by increasing urban demand for wildlife as food. Urban demand for forest vertebrates drives the "bushmeat crisis" in Africa (Bennett et al. 2007) and overexploitation of terrestrial and aquatic species is widely reported across Latin America and Asia (Corlett 2007; Peres \& Palacios 2007; Castello et al. 2012). Wildlife consumption behavior has been linked to poverty, substitution during food price shocks and wealth and prestige (Brashares et al. 2004; Brashares et al. 2011; Drury 2011).

Urbanization of forest wilderness is particularly important in the Brazilian Amazon, where eight million citydwellers are poor (IBGE 2010) and virtually nothing is known about the scale and drivers of urban consumption of wildlife. Remote headwaters have been abandoned through out-migration to local urban centers, motivated by poor access to public services, transport, and trade (Parry et al. 2010a, 2010b). Conservation and sustainable development initiatives in the prefrontier largely ignore urban population growth and instead invest in sustainable use reserves to avoid future deforestation (Newton 
et al. 2012). However, many Amazonian species risk extinction from overharvesting (Peres 2000; Castello et al. 2012), and assumptions that urban demand for forest wildlife in Amazonia is negligible (Nasi et al. 2011) may be incorrect. Commercial harvesting of forest and aquatic plants and animals is widespread, even in depopulated headwaters (Parry et al. 2010b), and sparsely scattered environmental institutions have long struggled to protect nature (Peres \& Terborgh 1995).

We examine the potential biodiversity impacts of urban growth in the forested wilderness by assessing urban wildlife consumption in Amazonia's forested prefrontier, which we define as the 73 municipalities with over $90 \%$ of their original forest cover still intact (Figure 1), holding 1.86 million square $\mathrm{km}^{2}$ of forest. Using household data from a representative sample of two prefrontier cities, Borba and Novo Aripuanã, we assess the prevalence and drivers of wildlife harvesting and consumption. These cities are both small (population 14,434 and 14,074 inhabitants, respectively), and poor (72\% and $74 \%$ of households living in absolute poverty, respectively (see Supporting Information [SI]). We then analyze census, law-enforcement and economic data from 429 municipalities to examine the potential for an Amazonian bushmeat crisis. Finally, we evaluate the policy dimensions of wildlife harvest and consumption, including environmental governance, poverty alleviation, and the wider Amazonian food system.

\section{Methods}

\section{Household surveys (see SI)}

Questionnaire surveys were administered in 153 households in Borba (BO) and Novo Aripuanã (NA), Amazonas State, Brazil (Figure 1). We undertook a rigorous randomized sample of households from BO $(n=61)$ and NA $(n=60)$ across all neighborhoods, combined with a selective sample of 16 recent rural-urban migrant households (herein "migrants") from each ( $\leq 5$ years since arrival). Our questionnaire captured socioeconomic variables, including: household origin, demography and income (formal and informal). We did not consider nonmonetary income or other dimensions of poverty. We also determined whether households engaged in any aquatic or forest harvesting (including commercial and subsistence) and asked about the consumption of bushmeat, freshwater fishes, chelonians, and caiman species within the previous 12 months. Participatory games were used to rank food preferences and for defining the consumption frequency of different forms of animal protein. We used generalized linear models with binomial error distributions to link socioeconomic variables with wildlife harvesting and species consumption.

\section{Large-scale trends}

We classified all municipalities in Brazil's Legal Amazon (covering 5.03 million $\mathrm{km}^{2}$ ) along a deforestation gradient based on the percentage of original forest cover still intact in 2011 (Figure 1). In 2010, the Legal Amazon had 782 municipalities and a population of 24.74 million people (urban: 17.83 million; rural: 6.91 million; IBGE 2010). We excluded from our analyses 353 municipalities whose original forest cover was less than $70 \%$ (i.e., partly outside the Amazon biome). The 429 municipalities included in our study cover 3.50 million $\mathrm{km}^{2}$, of which 2.56 million were forested in 2011 . This study area had 15.55 million human inhabitants in 2010 (urban: 11.28 million; rural: 4.27 million). We extracted federal data for 2011 for (1) closed season payments to fishermen, (2) payments through the conditional cash transfer program, Bolsa Família, and (3) the presence of federal environmental enforcement offices (IBAMA). See SI.

\section{Results Wildlife consumption}

Bushmeat was eaten at least once a month by nearly half $(44 \%)$ of urban households. The vast majority $(79 \%)$ had consumed bushmeat during the previous 12 months (Figure S2). Almost all (99\%) households had consumed fish, plus chelonians (48\%) and caiman (28\%) during this period. Urban households reported consuming a wide range of mammals ( $\leq 15$ species identified in total), birds $(\leq 12)$, fishes $(\leq 62)$, and reptiles ( $\leq 7$; Figure 2 ). Many of these species are vulnerable to overharvesting, reflected by IUCN threat statuses (for mammals, birds, and reptiles) including endangered ( $n=3$ species), vulnerable $(n=8)$ and near threatened $(n=5)$ species. In addition, there was widespread consumption of 12 fishes that are highly vulnerable to overharvesting (intrinsic vulnerability (IV) $\geq 57$ on $0-100$ scale, SI). Prevalent consumption (by $\geq 1 / 5$ of households) of threatened species spanned mammals (e.g., Tayassu pecari); reptiles (e.g., Podocnemis unifilis); and fishes (e.g., Arapaima gigas). Respondents liked eating wildlife-all households had at least one member who liked the taste of fish, followed by bushmeat $(92 \%)$, chelonians $(78 \%)$, and caiman $(46 \%)$.

Species face divergent threats of over-exploitation because socio-economic characteristics determine access to different species, linked to income and rural livelihoods. Consumption of 5 out of 26 harvested species with robust models was strongly associated with income poverty (all associations were positive; relative importance from model averaging $\geq 0.5$ ). Nevertheless, wealth also drives consumption as three species, including two mammals and a large "prestige" fish (Colossoma macropomum) were 


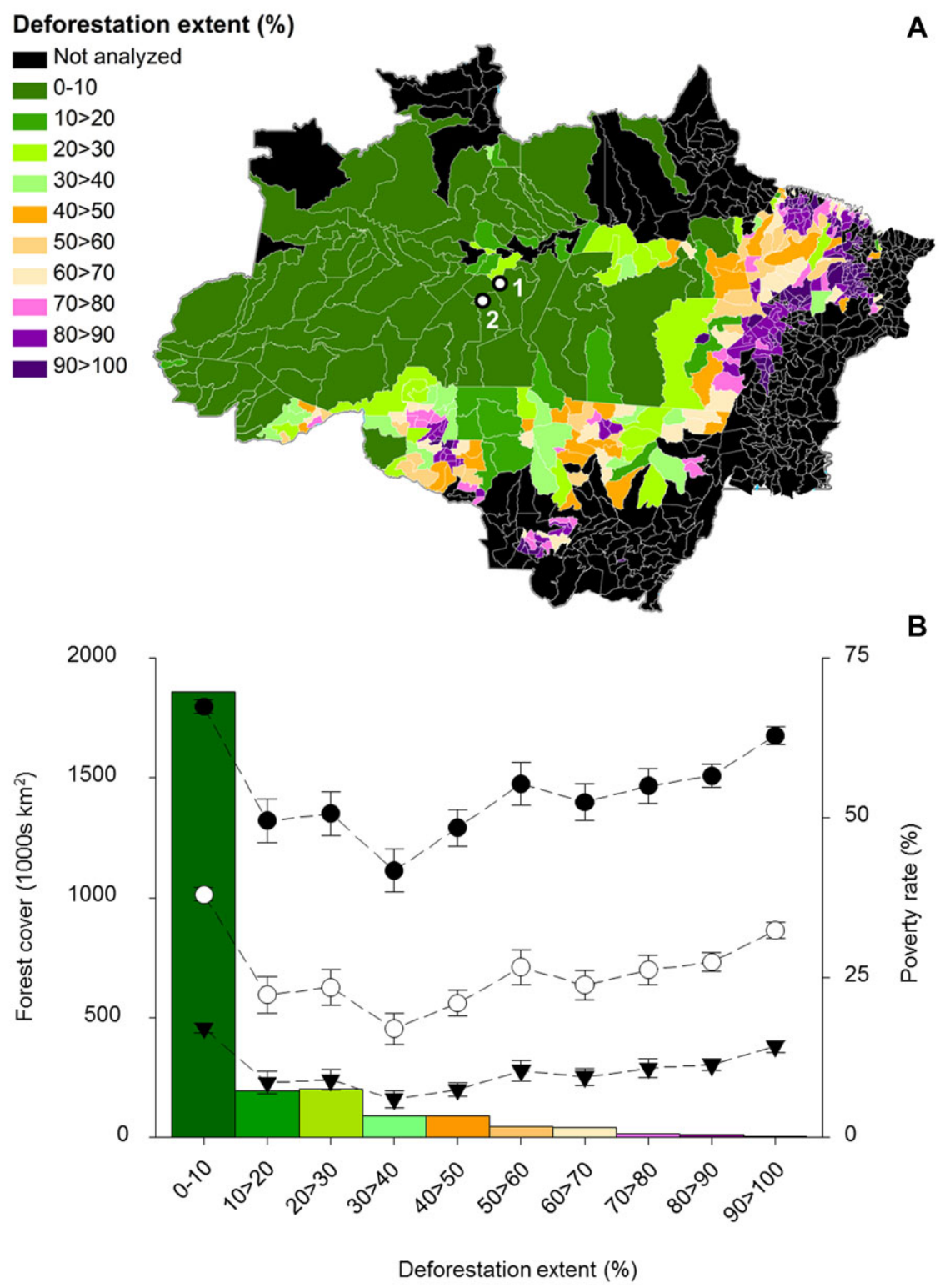

Figure 1 Municipalities in the Brazilian Amazon classified by original forest remaining and urban poverty. A) Deforestation extent (2011) in the Brazilian Amazon with municipalities $(n=429)$ classified by extent of original forest lost according to PRODES images. The prefrontier is defined as intact municipalities with less than $10 \%$ forest loss. Municipalities were not analyzed $(n=353)$ if they originally had less than $70 \%$ forest cover or were less than 70\% covered by the 2011 PRODES image. Household surveys were conducted in two focal towns: (1) Borba and (2) Novo Aripuanã, both in Amazonas State. (B) Total forest cover (colored bars) and urban poverty rates (mean \pm SE): absolute poverty (black circles; up to half a Brazilian minimum salary per capita, equal to R\$8.50 [US\$3.65]/day/capita); extreme poverty (white circles; up to 1/4 minimum salary per capita, equal to R $\$ 4.25$ [US $\$ 1.82$ ]/day/capita) and United Nations' extreme poverty (inverted black triangles; US\$1.25/day/capita).

strongly associated with wealthier households (Figure 4). Consumption of three fish species was strongly associated with recent rural migrants $(\leq 5$ years since arrival; Figure S4). These species have low economic values, including a taboo catfish highly vulnerable to overexploitation (Brachyplatystoma filamentosum; IV $=66 / 100$; Figure 2; Table S5).

\section{Wildlife harvest}

Income poverty was a strong predictor of fishing (28\% of households, overall), hunting (12\%) and the consumption of many (but not all) modelled species. Among the poorest households, $45 \%$ fished and $23 \%$ hunted, compared to only $7 \%$ and $3 \%$ of the wealthiest 
Figure 2 Wildlife consumption by urban Amazonian households combined with conservation threat status of species/groups. Horizontal bars show the percentage of households that had consumed each species during the previous 12 months and bars are colored according to broad taxonomic groups. Black dots indicate IUCN threat status for mammals, birds and reptiles (least concern (LC); data deficient (DD); near threatened (NT); vulnerable (VU); endangered (EN); iucnredlist.org). When local names of nonfishes could not be resolved to a single species, the IUCN red list was used to identify plausible species found within the study area, for which threat status of all is shown. Threat status of fishes (white dots) is limited to an intrinsic vulnerability (IV) score taken from fishbase.org, which is based upon life history characteristics that reflect the capacity of a species or population to tolerate impacts such as harvesting. Larger values of IV indicate higher vulnerability to overfishing, and values $\geq 57$ indicate species are highly vulnerable. When local names of consumed fishes could not be resolved to a single species, we identified plausible species found within the study area (see SI and fishbase.org) and here show the mean vulnerability score for each species group (see Table S5). An additional 13 species consumed by $<1 \%$ of households are not shown here, and include fishes (Brachyplatystoma vaillantii [IV $=72]$; Cynodon gibbus [IV =24]; Leiarius marmoratus [IV = 54]; Pareiorhaphis duseni [IV = 10]; Satanoperca lilith [IV = 33]; Serrasalmus rhombeus [IV = 35]; Uaru amphiacanthoides [IV = 33]) and birds (Crax globulosa [EN]; Dendrocygna autumnalis [LC]; Leptotila sp. [LC]; Pipile cujubi [LC]; Tinamus major [NT]).

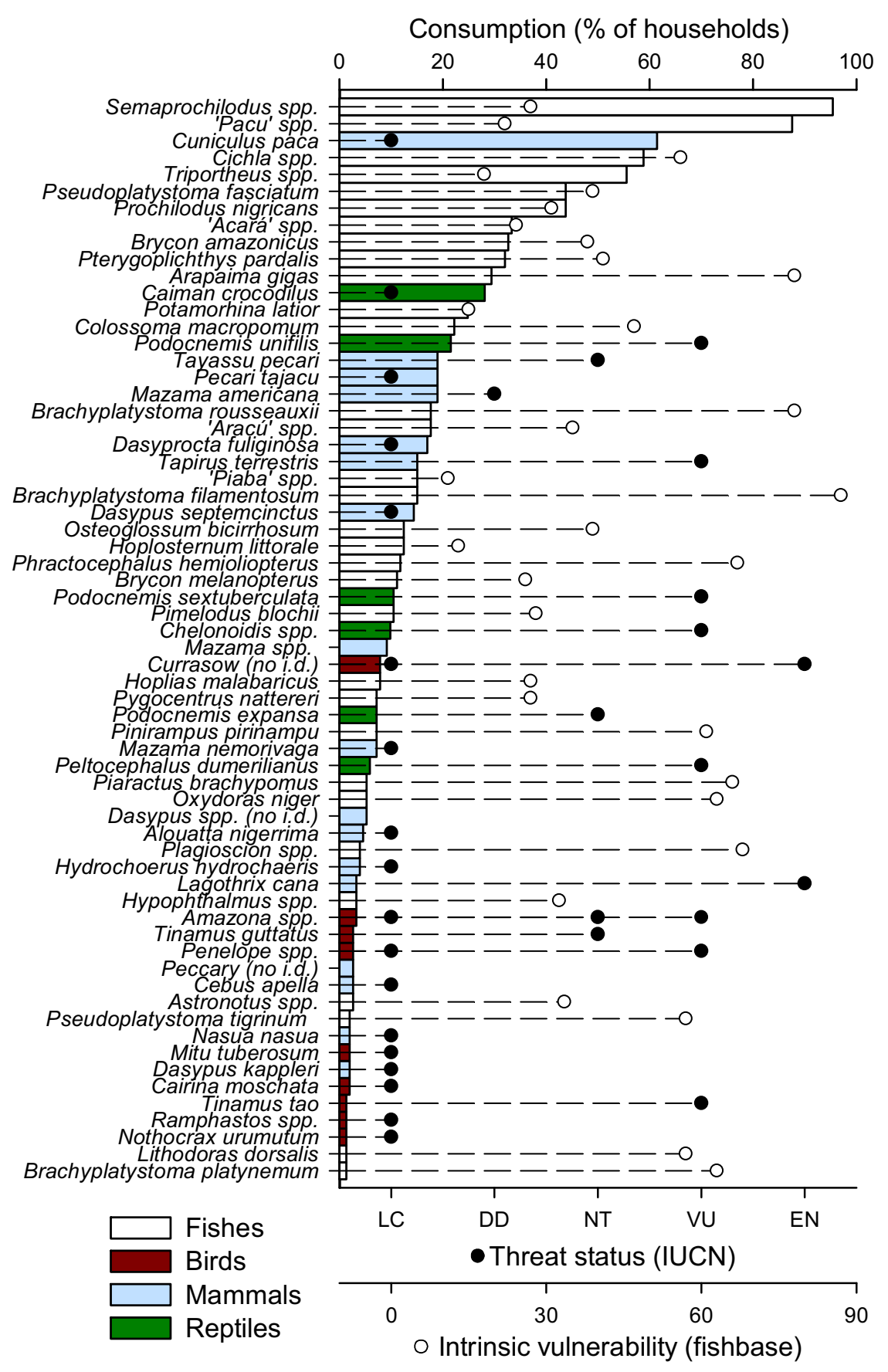

00 


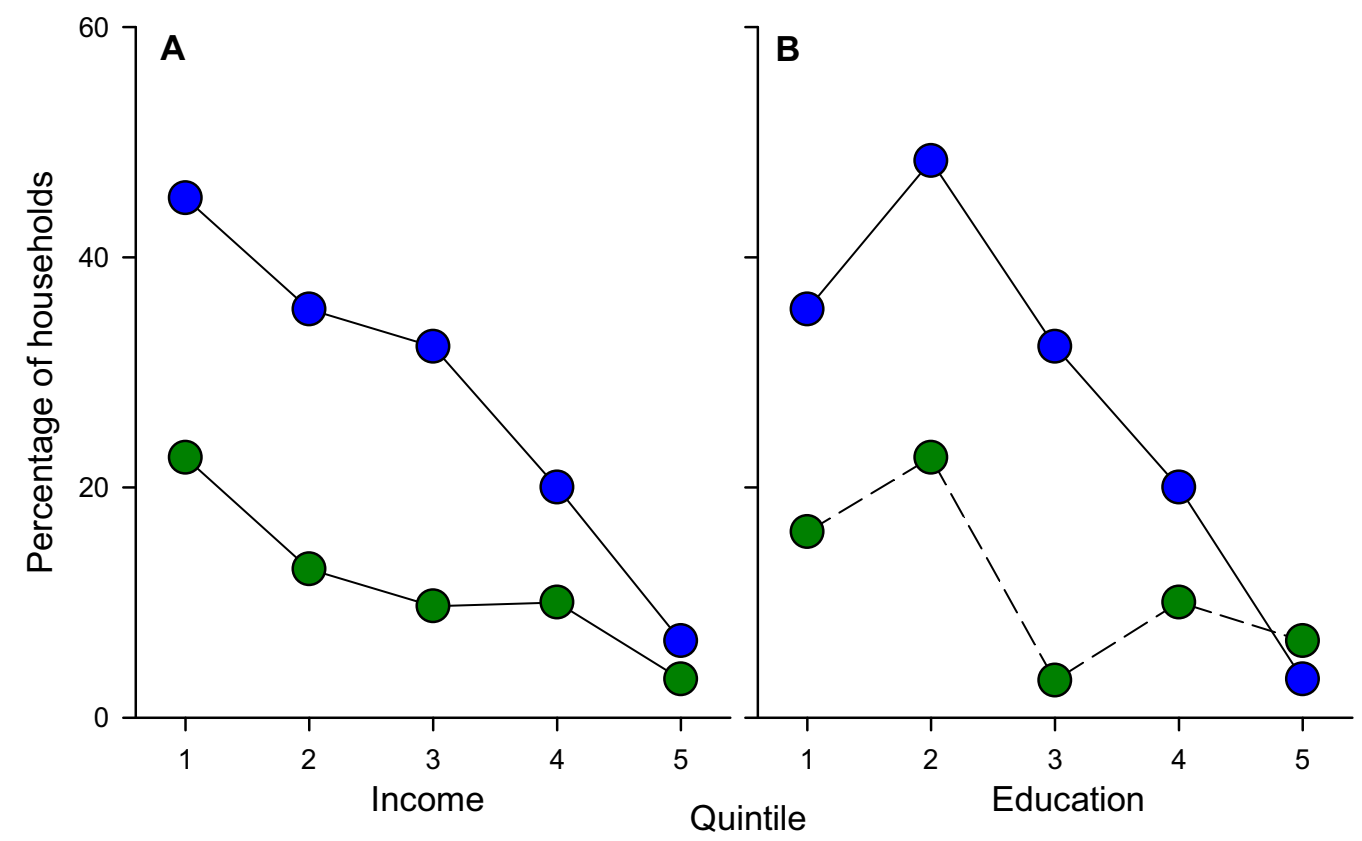

Figure 3 Predictors of fishing (blue circles) and hunting activity (green circles) by urban households. These are examples of predictors used in multimodel inference of these activities by urban households $(n=153)$ in the Amazonian prefrontier: (A) income (quintiles of per capita monthly income) and (B) education (quintiles of years of education of the household head). The relative importance of each predictor is indicated by solid lines (high relative importance [ $\geq 0.5]$ ) and dashed lines (lower relative importance $[<0.5]$ ). Full model summaries are provided in Table S3.

= 10,000 inhabitants; Figure S6) but rapidly expanding due to rural-urban migration and internal growth, growing by $54 \pm 6$ SE percent in the decade to 2010 and nearly 10 -fold since 1970. Urban income poverty, indicative of rural livelihoods and wildlife harvest, is higher in the prefrontier than any other forest-cover class, whether measured by the number or proportion of people that are poor (Figure 1 and S7).

A city-driven wild-meat crisis in the Amazonian prefrontier could not currently be prevented by command and control measures to reduce supply because federal resources to combat wildlife crime are extremely limited. The Brazilian Institute of Environment and Renewable Natural Resources (IBAMA) is responsible for enforcing environmental legislation outside of protected areas and its presence in the prefrontier is restricted to 13 larger cities. In fact, only one of the 55 prefrontier cities with fewer than 19,500 inhabitants had an IBAMA office in 2011 , despite the 1.16 million $\mathrm{km}^{2}$ of forest under the stewardship of these urban centers $(62 \%$ of all forest cover in the prefrontier; $45 \%$ of forest cover of 429 Amazonian municipalities in this study). However, investment in fisheries management in the prefrontier was higher (both total and per inhabitant) than in any other deforestation class and was distributed amongst all but one of the municipalities. During the 4 month closed season in 2011, 43,727 artisanal fishers were paid a total of US $\$ 48.4$ million by the federal government (Figure 5). The prefrontier also received the secondhighest investment in federal conditional cash transfers to poor families, totaling US\$165 million in 2011 (Figure 5).

\section{Discussion}

Urbanization is supposed to save threatened tropical biodiversity (Aide \& Grau 2004; Wright \& Muller-Landau 2006), and an Amazonian bushmeat crisis has apparently been avoided because urban Amazonians do not eat forest species (Nasi et al. 2011). Our results suggest the assumptions underlying these arguments need to be re-evaluated-we argue that urban expansion poses a significant and overlooked threat to biodiversity. We demonstrate that urban consumption of wildlife is widespread in Amazonia's forested prefrontier with poor urban households harvesting wildlife (van Vliet $\&$ Mbazza 2011) and wealthy urbanites driving an illegal trade in prestige threatened species (Drury 2011; Wilkie et al. 2011). Only $12 \%$ of households went hunting whereas $79 \%$ consumed bushmeat, indicating that city-dwellers who not harvest wildlife, instead, purchase it for consumption. Our results are likely to be indicative 

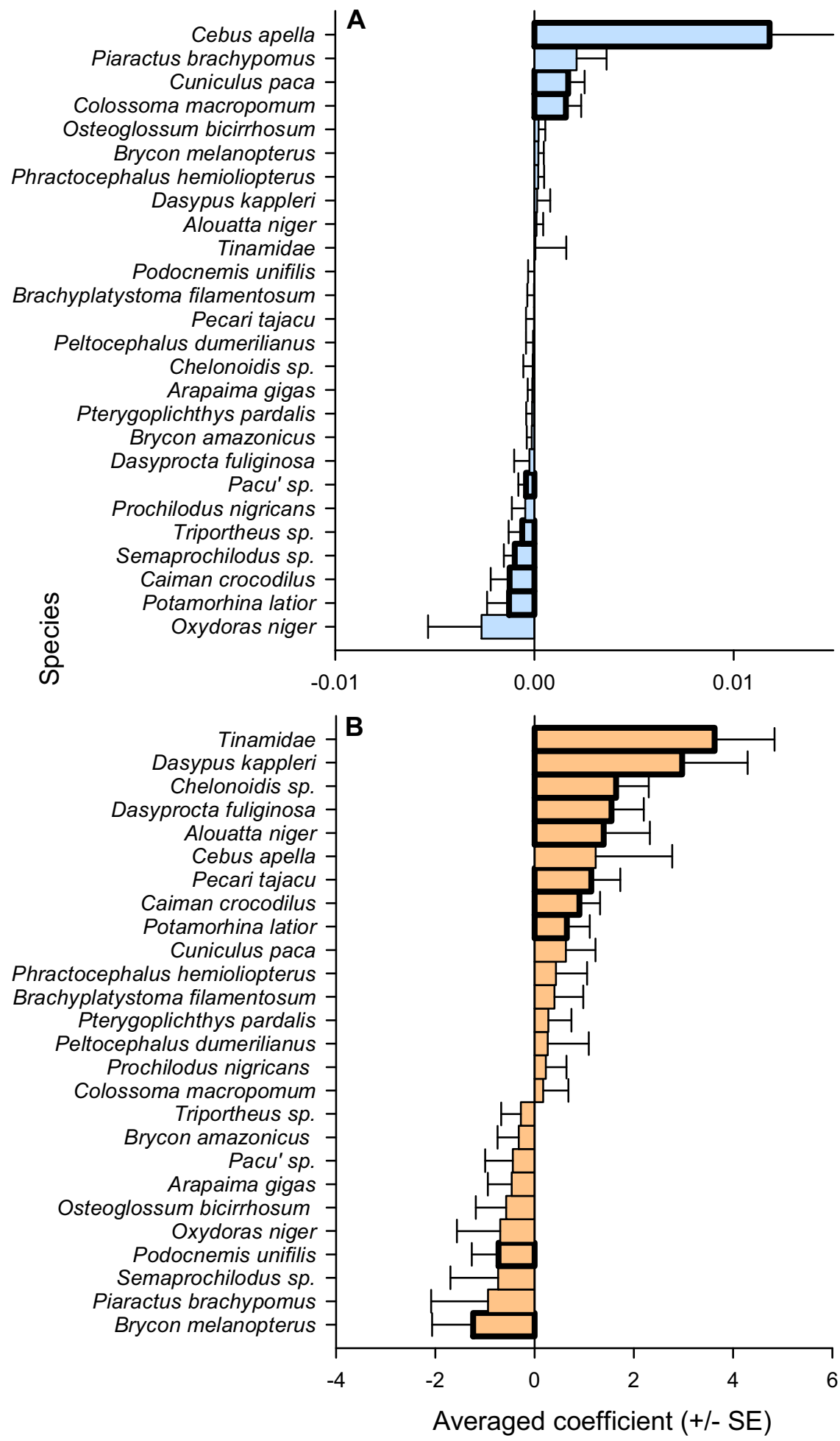

Figure 4 Influence of income and harvesting behavior on wildlife consumption by urban Amazonians. Specifically, the influence of (A) per capita income (from formal and informal employment plus government benefits) and (B) harvesting behavior (whether a household practiced hunting [mammals or birds] or fishing [fishes and reptiles] on wildlife consumption by urban Amazonian households, based on averaged coefficients [ \pm SE]) taken from multimodel inference of questionnaire responses. Positive values indicate species that are more likely to be consumed by wealthier households or those that practice hunting or fishing. Negative values indicate the opposite. Bars with thick borders indicate a high relative importance value $(\geq 0.5)$ for this variable. 


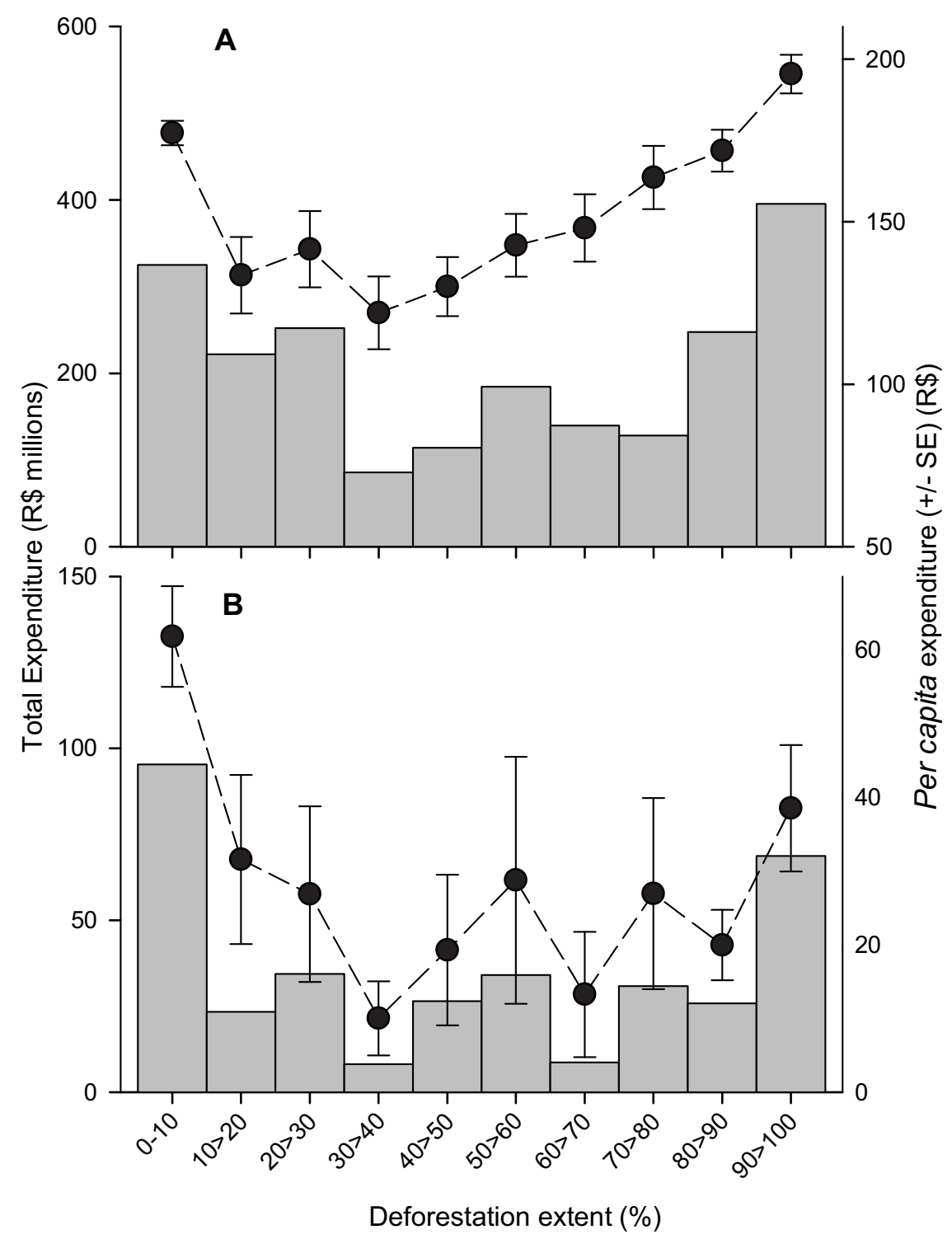

Figure 5 Government expenditure on (A) poverty alleviation and (B) closed season payments to Amazonian fishers in 2011. Total expenditure (vertical bars; left axis) and per capita expenditure (black dots; mean $\pm \mathrm{SE}$; right axis) of the Brazilian federal government on (A) conditional cash transfers for poverty alleviation (Family Grant or "Bolsa Família") and (B) payments of minimum salaries to fishers during closed seasons to Amazonian municipalities in 2011 , along a deforestation gradient of 429 municipalities.

of a broader problem in the Amazonian prefrontier (Figure 1) as many urban Amazonians are food insecure (Yuyama et al. 2007) and have deficient access to Brazil's road-based food distribution network (Fenley et al. 2007) yet good access to forests and rivers. Urban consumption of wildlife may partly explain the declining abundance of many Amazonian vertebrates (Peres 2000; Castello et al. 2012), and could compromise ecosystem functioning (Harrison et al. 2013), even in areas with high forest cover remaining.
Addressing illegal or unsustainable wildlife consumption in growing urban centers requires policies that balance environmental governance (cost-efficient biodiversity conservation) with social welfare (ensuring fairness, food security, and livelihoods; Agrawal et al. 2008; Golden et al. 2011). We outline policy responses that could improve environmental governance (e.g., parks, fines, incentives) or promote poverty alleviation (e.g., empowering women, agricultural innovation) in the Amazonian prefrontier. 


\section{Improving environmental governance}

In Brazil, eating wild-caught bushmeat, caiman or turtles is illegal unless for rural subsistence, so most of the households we interviewed were breaking the law. Those caught in possession of these taxa face confiscation of carcasses and harvesting equipment, a hefty fine (thousands of dollars) and imprisonment. Despite heavy penalties there is very low probability of detection, arrest, prosecution or conviction, and thus limited deterrence of illegal activity (Robinson et al. 2010). Nevertheless, supplying sufficient resources to deter all urban consumption of bushmeat, turtles or caiman would be unrealistic, hugely costly and also inefficient because species' tolerance to harvest varies hugely (Robinson et al. 2010). Furthermore, the legalization of hunting only for rural subsistence is unrealistic (Bowen-Jones et al. 2003) given complex livelihoods strategies, multisited households and the importance of rural safety nets for the urban poor (Padoch et al. 2008; this study).

Perhaps hunting policies could be more effective if they followed some aspects of fisheries legislation? The Brazilian government attempts to conserve vulnerable fish species through minimal size limits and/or a closed season (Table S5) during which fishers are paid a minimum salary (Figure 5). Worryingly, this closed-season could actually have unintended negative consequences if a fisheries closed season drives demand for bushmeat by reducing access to fish (Brashares et al. 2004). For terrestrial species, legalizing a limited trade in rodents is plausible as they are both preferred (especially Cuniculus paca) and relatively harvest-tolerant (high intrinsic rates of population increase). Hunting could be allowed at certain times of year, where reproduction is seasonally predictable, or could allow hunting of males rather than females, if hunters were able to distinguish. However, persuading hunters to be highly selective in killing animals would be difficult because it leads to reduced catch-per-unit-effort. Also, conserving those preferred yet vulnerable species is challenging because overexploitation can increase market prices and drive species toward extinction (Hall et al. 2008).

In summary, current environmental governance in Amazonia is ineffective for conserving vulnerable species or promoting the sustainable use of terrestrial vertebrates, caimans or turtles. Blanket bans and heavy punishments are poorly enforced and offer limited deterrent to illegal behavior. Given limited resources, we suggest a shift toward more targeted legislation focused on conserving the most vulnerable species and those with important ecological roles, whilst allowing some trade in harvest-tolerant species. However, a more selective approach still requires a governmental presence on-the-ground and we argue that federal spending should increase to allow for staffed IBAMA offices in a much greater number of prefrontier towns.

\section{Poverty alleviation, policy, and population growth}

Policy interventions to improve living standards and eradicate poverty could affect wildlife consumption in two contrasting ways. First, boosting incomes among the urban poor could alter individual harvesting behavior or food consumption patterns (both food types and amount). Second, escaping poverty is associated with long-term reductions in the total fertility rate (children per woman in her lifetime), which would limit future growth in the number of urban consumers.

In Brazil, efforts to eradicate poverty and hunger have focused on Bolsa Família, a cash transfer program, conditional on school attendance and up-to-date vaccinations. Cities in the forested prefrontier are the poorest in Amazonia (Figure 1) and these municipalities are also the greatest beneficiaries of Bolsa Família (US\$165m in 2011; Figure 5). Almost half of the poorest urban households we surveyed relied on wildlife for income or food (Figure 3). As money from Bolsa Família is used to buy food (IBASE 2008), a simple analysis would suggest that poor urban households have less necessity than before to harvest wildlife. However, a nutrition transition (to more meat, fewer carbohydrates) in tropical countries is being driven by rising incomes therefore payments from Bolsa Família may increase per capita demand for all animal products, including wildlife. In addition, because Bolsa Família improves school attendance and future earnings (Glewwe \& Kassouf 2012), it could increase the longer term demand for preferred high-value wildlife species.

Future wildlife demand from Amazonian cities will be influenced by demographic transition. In the Amazonian prefrontier the urban population is growing rapidly (4.5\% annual growth, 16 year doubling-time; SI) due to rural-urban migration, high fertility rates and population momentum. In this respect, Bolsa Família may limit wildlife demand, as (despite rhetoric) it does not encourage larger families (Signorini \& Queiroz 2011), and could help control population growth by providing women in prefrontier cities with education and employment opportunities (Bloom 2011).

\section{A new research agenda}

In the longer term, reducing unsustainable wildlife harvesting and consumption requires the development of a sustainable food system within forested wilderness regions. This will require a new interdisciplinary and 
policy-relevant research agenda that seeks urban food security, innovative agricultural land-uses and resilience to extreme climatic events. Although wildlife demand is reduced by the availability of alternative economical sources of animal protein these also tend to be direct or indirect drivers of deforestation. For instance, increased cattle-ranching in the prefrontier would lead to cheaper beef and more deforestation. What about eating chickens-now a staple in the Amazonian diet (Nardoto et al. 2011; Figure S2)? Feeding remote cities with imported battery-farmed poultry fed on maize and soy has important but poorly understood implications for landuse change elsewhere. Research is also needed to understand the effects of extreme droughts and floods on Amazonian wildlife (mortality, demand as food, accessibility, detectability) and food security in cities dependent on long-distance river transport. Fish-farming could enhance food security and alleviate pressure on harvested wildlife although the scale and nature of this sector in Amazonia is another important research gap. Also, who is consuming wildlife in Amazonia's metropolitan areas and how do the commodity chains operate? Finally, how do wildlife harvest and consumption relate to other dimensions of urban poverty, beyond cash income (e.g., health, nonmonetary income, vulnerability [see SI])?

\section{Conclusion}

We have shown that urban Amazonians consume many vertebrate species, including those vulnerable to extinction. Reducing wildlife harvest and consumption to a narrower suite of harvest-tolerant species will require improved governance to limit the wildlife supply and providing price-sensitive urban consumers with economical alternative sources of animal protein in order to limit demand-side pressures. Effective detection and deterrence of illegal behavior is necessary to protect the most preferred and vulnerable species, plus farming for some fishes, caimans, and turtles. Poverty-alleviation programs may accelerate a long-term transition from consumption of wildlife as an economical source of protein for the poor to luxury food for the wealthy. Urban Amazonians are often ignored in scientific debates about the fate of remaining forests, even though their wealth, well-being and fertility decisions will affect resilience to future environmental change. Conserving biodiversity and ensuring human food security in urbanized forest wilderness will require poverty alleviation, innovation and improved environmental governance.

\section{Acknowledgments}

We are grateful to the people and governments of Borba and Novo Aripuanã for participating in this research.
We thank R. Ewers, T. Haugaasen, D. Edwards, A. Keane and A. Lees for useful comments. Financial support was provided by Lancaster University and the Center for International Forestry Research (CIFOR).

\section{Supporting Information}

Additional Supporting Information may be found in the online version of this article at the publisher's web site:

Figure S1 Population growth and urbanization trends in the Brazilian Amazon and the Democratic Republic of Congo.

Figure S2 Minimum consumption frequency of wild (triangles and squares) and domesticated sources (circles) of animal protein by urban households.

Figure S4 Influence of household origins, rural livelihoods and socio-economic factors on wildlife consumption by urban Amazonians.

Figure S6 Mean ( \pm SE) (a) size and (b) remoteness of urban centers in the Brazilian Amazon (subset of 429 municipalities) along a deforestation gradient.

Figure S7 Urban poverty in the Brazilian Amazon, along a deforestation gradient.

Table S3 Results of multimodel inference in which model averaging of dredge results has been used to average coefficients of predictor variables for fishing or hunting (practiced by a household member).

Table S5 Fish species consumed by urban households, identified using local names.

\section{References}

Agrawal, A., Chhatre, A. \& Hardin, R. (2008). Changing governance of the world's forests. Science, 320, 1460-1462.

Agrawal, A. \& Redford, K.H. (2006). Poverty, development, and biodiversity conservation: shooting in the dark? Pages 58. Wildlife Conservation Society, New York.

Aide, T.M. \& Grau, H.R. (2004). Ecology: enhanced: globalization, migration, and Latin American Ecosystems. Science, 305, 1915-1916.

Bennett, E.L., Blencowe, E., Brandon, K. et al. (2007). Hunting for consensus: reconciling bushmeat harvest, conservation, and development policy in west and central Africa. Conserv. Biol., 21, 884-887.

Bloom, D.E. (2011). 7 billion and counting. Science, 333 , 562-569.

Bowen-Jones, E., Brown, D. \& Robinson, E.J.Z. (2003). Economic commodity or environmental crisis? An interdisciplinary approach to analysing the bushmeat trade in central and West Africa. Area, 35, 390-402.

Brashares, J.S., Arcese, P., Sam, M.K., Coppolillo, P.B., Sinclair, A.R.E. \& Balmford, A. (2004). Bushmeat hunting, 
wildlife declines, and fish supply in West Africa. Science, 306, 1180-1183.

Brashares, J.S., Golden, C.D., Weinbaum, K.Z., Barrett, C.B. \& Okello, G.V. (2011). Economic and geographic drivers of wildlife consumption in rural Africa. Proc. Natl. Acad. Sci. U. S. A., 108, 13931-13936.

Brooks, T.M., Mittermeier, R.A., da Fonseca, G.A.B. et al. (2006). Global biodiversity conservation priorities. Science, 313, 58-61.

Castello, L., McGrath, D.G., Hess, L.L. et al. (2012). The vulnerability of amazon freshwater ecosystems. Conserv. Lett., 6, 217-229.

Corlett, R.T. (2007). The impact of hunting on the mammalian fauna of tropical Asian forests. Biotropica, 39, 292-303.

Drury, R. (2011). Hungry for success: urban consumer demand for wild animal products in Vietnam. Conserv. Soc., 9, 247-257.

Fenley, C.A., Machado, W.V. \& Fernandes, E. (2007). Air transport and sustainability: lessons from Amazonas. Appl. Geogr., 27, 63-77.

Glewwe, P. \& Kassouf, A.L. (2012). The impact of the Bolsa Escola/Familia conditional cash transfer program on enrollment, dropout rates and grade promotion in Brazil. $J$. Dev. Econ., 97, 505-517.

Golden, C.D., Fernald, L.C.H., Brashares, J.S., Rasolofoniaina, B.J.R. \& Kremen, C. (2011). Benefits of wildlife consumption to child nutrition in a biodiversity hotspot. Proc. Natl. Acad. Sci. U. S. A., 108, 19653-19656.

Hall, R.J., Milner-Gulland, E.J. \& Courchamp, F. (2008). Endangering the endangered: the effects of perceived rarity on species exploitation. Conserv. Lett., 1, 75-81.

Harrison, R.D., Tan, S., Plotkin, J.B. et al. (2013). Consequences of defaunation for a tropical tree community. Ecol. Lett., 16, 687-694.

IBASE. (2008). Repercussões do programa Bolsa Família na segurança alimentar e nutricional das famílias beneficiadas. Pages 20. Instituto Brasileiro de Análises Sociais e Econômicas (Ibase), Rio de Janeiro, Brazil. http://www.ibase.br/userimages/ibase 'bf sintese site.pdf.

IBGE. (2010). Censo demografico da população. Instituto Brasileiro de Geografia e Estatistica.http://downloads.ibge.gov.br/downloads' estatisticas.htm

Joppa, L.N., Loarie, S.R. \& Pimm, S.L. (2008). On the protection of "protected areas". Proc. Natl. Acad. Sci. U.S.A., 105, 6673-6678.

Nardoto, G.B., Murrieta, R.S.S., Prates, L.E.G. et al. (2011). Frozen chicken for wild fish: nutritional transition in the Brazilian Amazon region determined by carbon and nitrogen stable isotope ratios in fingernails. Am. J. Hum. Biol., 23, 642-650.

Nasi, R., Taber, A. \& Vliet, N.V. (2011). Empty forests, empty stomachs? Bushmeat and livelihoods in the Congo and Amazon Basins. Int. Forest. Rev., 13, 355-368.
Newton, P., Nichols, E.S., Endo, W. \& Peres, C.A. (2012). Consequences of actor level livelihood heterogeneity for additionality in a tropical forest payment for environmental services programme with an undifferentiated reward structure. Glob. Environ. Change, 22, 127-136.

Padoch, C., Brondízio, E., Costa, S., Pinedo-Vasquez, M., Sears, R.R. \& Siqueira, A. (2008). Urban forest and rural cities: multi-sited households, consumption patterns, and forest resources in Amazonia. Ecol. Soc., 13(2), 2, http:// www.ecologyandsociety.org/vol13/iss 12/art12/.

Parry, L., Day, B., Amaral, S. \& Peres, C. (2010a). Drivers of rural exodus from Amazonian headwaters. Popul. Environ., 32, 137-176.

Parry, L., Peres, C.A., Day, B. \& Amaral, S. (2010b). Rural-urban migration brings conservation threats and opportunities to Amazonian watersheds. Conserv. Lett., 3, 251-259.

Peres, C.A. (2000). Evaluating the impact and sustainability of subsistence hunting at multiple Amazonian forest sites. Pages. 31-56 in J.G. Robinson, E.L. Bennett, editors. Hunting for sustainability in tropical forests. Columbia University Press, New York.

Peres, C.A. \& Palacios, E. (2007). Basin-wide effects of game harvest on vertebrate population densities in Amazonian forests: implications for animal-mediated seed dispersal. Biotropica, 39, 304-315.

Peres, C.A. \& Terborgh, J.W. (1995). Amazonian nature reserves: an analysis of the defensibility status of existing conservation units and design criteria for the future. Conserv. Biol., 9, 34-46.

Robinson, E.J.Z., Kumar, A.M. \& Albers, H.J. (2010). Protecting developing countries' forests: enforcement in theory and practice. J. Nat. Resour. Policy Res., 2, 2538.

Signorini, B.A. \& Queiroz, B.L. (2011). The impact of the Bolsa Família programme on beneficiaries' fertility. Pages 24 . Universidade Federal de Minas Gerais, Belo Horizonte, Brazil.

van Vliet, N. \& Mbazza, P. (2011). Recognizing the multiple reasons for Bushmeat consumption in Urban areas: a necessary step toward the sustainable use of wildlife for food in Central Africa. Hum. Dimen. Wildl., 16, 45 54.

Wilkie, D.S., Bennett, E.L., Peres, C.A. \& Cunningham, A.A. (2011). The empty forest revisited. Ann. N. Y. Acad. Sci., 1223, 120-128.

Wright, S.J. \& Muller-Landau, H.C. (2006). The future of tropical forest species. Biotropica, 38, 287-301.

Yuyama, L.K.O., Aguiar, J.P.L., Pantoja, L. et al. (2007). Segurança/insegurança alimentar em famílias urbanas e rurais no estado do Amazonas: I. validação de metodologia e de instrumento de coleta de informação. Acta Amazonica, 37, 247-252. 